\title{
Prospects of Sustainable Livestock Farming in NEH Region of India
}

\author{
R. Joseph Koireng ${ }^{1 *}$, P.S. Rolling Anal' ${ }^{2}$, Kalyan Jana ${ }^{3}$ and K.H. Priya Devi ${ }^{3}$ \\ ${ }^{1}$ Directorate of Research, Central Agricultural University, Imphal - 795004, Manipur, India \\ ${ }^{2}$ ICAR Research Complex for NEH Region, Umroi road, Umiam, Meghalaya-793103. India \\ ${ }^{3}$ Directorate of Research, Bidhan Chandra Krishi Viswavidyalaya, Kalyani-741235, Nadia, \\ (West Bengal), India \\ *Corresponding author
}

\section{A B S T R A C T}

Livestock farming forms an integral part in the economy of the NEH Region of India and plays an important role in the mixed crop farming system. In addition, high diversity in

Keywords

Grassland,

wasteland,

Livestock farming, NEH Region

Article Info

Accepted:

12 December 2017

Available Online:

10 January 2018 livestock composition is the characteristic features of the mainland of this region. The region obtains high potential of milk production because of availability of fodder as a form of extensive grasslands, wasteland, shrub and fodder trees. Livestock, other than milk production, are widely used for manure, plowing fields and transportation of goods. The availability of extensive grasslands, waste land and feasible climatic conditions manifest a way for sustainable livestock farming in NEH Region, both in hill and valley district, where production of milk is high. Hilly regions are generally known for rearing of drought animals with low milk producing capacity. This paper aims to discuss on the prospects of sustainable livestock farming and to trace the temporal changes that took place over the past years in terms of livestock population, composition, and the governmental policies and planning for developing livestock sector. It draws implications on these experiences for livestock planners and policy-makers and raises several research issues related to livestock sector development.

\section{Introduction}

Livestock rearing is an integral component of hill farming systems. In NEH states, there is a dynamic relationship among common property resources (CPRs), livestock, and crops in the mixed crop-livestock farming systems. Livestock depend, to a great extent, on fodder grown on the community land, forestland, and as well as on crop residue. Meanwhile, the animals provide milk, manure, meat, and much needed draught power. Livestock are therefore, an important to the sustainability of hills farming. More than $75 \%$ of the population's livelihood is based on livestock rearing under subsistence cereal farming systems.

In NEH Region, landholdings are small and fragmented. It consists mostly of marginal mid-slopes and valley regions. The concentration of human settlement is high in 
some state. Agricultural farming is based upon the centuries old practices, carried on the narrow patches of terraced fields. The production and productivity of subsistence cereal crops is very low. The majority of farmers operate mixed crop-livestock farming systems under different types of agroecosystems. Geographic and topographic variations have combined to provide a microcosm of the Earth's livestock farming systems (Jodha and Shrestha, 1990), which can precisely be visualized in the fragile terrain of this region.

The mounting pressure of increasing human populations on the mid-slopes and valley regions provide a way for decreasing land resources with fragmentation of agricultural land over the centuries. Under such circumstances, sustainable livestock farming, which is inevitable, provides a base for livelihood of the populace. Here, the term sustainable livestock farming refers for rearing of a sizeable livestock, producing enough milk and milk based products and balancing draught power and fodder supply in fragile ecosystem. Therefore, the sustainability in livelihood, of the marginal farmers whose economy is tremendously based upon mixed subsistence crops-livestock farming, could be attended.

The most common livestock species in the mixed crop farming systems are cattle, buffaloes, sheep and goats. Milk at a large scale produced from cow, which is sold at the service centers of the nearby villages and is the partial source of income of the people. Bullocks are mainly used for plowing the fields. Goats are reared at a large scale, particularly above $1000 \mathrm{~m}$ and used for meat, wool. Horses and ponies are also reared moderately and mostly used for transportation between the service centers and remote villages. Manure is obtained from cattle, buffaloes, and goats.

\section{Study area}

The northeastern Himalayan region comprises of eight states: Arunachal Pradesh, Assam, Manipur, Meghalaya, Mizoram, Nagaland, Sikkim and Tripura. The region has total geographical area of 262180 sq. km (FSI, 1999). Climate varies from near tropical in the plains to alpine in the hills, based on which the region has been classified into six agroclimatic zones (Table 1). The soil is acidic in nature and the $\mathrm{pH}$ ranges from 4.0 to 6.8 . The low $\mathrm{pH}$ is attributed to leaching of bases from the soil under the influence of high rainfall. On an average $54.48 \%$ of total geographical area is under forest cover. Out of total forest area, about $44.14 \%$ comes under protected and reserved area and rest $55.86 \%$ comes under unclassified forest (FSI, 1999). Livestock is an integral component of agricultural system in the region and with the availability of large area of uncultivable and grass land, animal husbandry has tremendous potentiality in this region. Although agriculture is the prime source of livelihood for a majority of rural population in the North-Eastern region (NER) of India, dependence on livestock as an alternative source of income is significant. About 30 per cent of landless and 48 per cent of marginal households keep livestock in the NEH Region (NSSO, 2003). Livestock sector can also generate alternate livelihood to the marginal section of the society.

\section{Materials and Methods}

In the present study wide range of data, primary as well as secondary, were collected. Primary data were gathered through the case studies of the villages, selected based on their location, altitude, and nature of economy. Similarly, a case study of a dairy farm was done to facilitate the data interpretation, which also shows the potential of dairy farming in the study region. Secondary data were mainly gathered from the Directorate of Economics 
and Statistics, Department of Agriculture \& Cooperation. This study is also based upon the participation and observation method after rapid field visit. Apart from these, archival data were widely used.

\section{Livestock composition and distribution}

A large variety of livestock is reared in the region. While cattle, buffaloes, sheep, goats and pigs are reared in all states of the region, mithuns are available in Arunachal Pradesh, Manipur, Mizoram and Nagaland and yaks are found in Arunachal Pradesh and Sikkim (Table 2). According to the 18th livestock census, total livestock and poultry population in north eastern region is 7911 and 15097 thousand, respectively (Table 2).

The livestock density varies according to the agro-geographic condition as well as the preference of the people and their needs. Majority of the states including Arunachal Pradesh, Manipur, Meghalaya and Tripura are having highest population density of cattle than any other livestock whereas overall, population density of total livestock and poultry is highest in Tripura and least in Mizoram and Sikkim, respectively.

Cattle (cows and bullocks), buffaloes, goats, sheep, pig, horse, ponies, yaks and mithun constitute the livestock composition in this region. A large proportion of livestock is raised under the mixed cropping system in NEH Region. Cattle are most common followed by pig, Goat, Mithun, buffaloes, sheep and yaks in mixed crop farming systems in the NEH Region of India. The landholdings are small and livestock provide a critical supplement to farm incomes as manure. Bullocks are used for plowing farmland. Mahendra Dev (1994) cautioned that livestock pressure under mixed crop-livestock farming system has been increased. In the low hills, the average number of livestock per household was 14 animals, out of which cattle accounting for maximum number, followed by sheep, goat, pig, duck and poultry. In the mid-hills, the numbers were 9 animals in mixed farming systems and nine animals in vegetable-based farming systems.

Pig constitutes maximum livestock population; cattle rank second with, followed by goats (Table 2). The population of crossbreed livestock is very low. Rearing of various species of animals' is very common but their composition and distribution vary from valleys (about $500 \mathrm{~m}$ ) to the highly elevated mountain regions $(3500 \mathrm{~m})$. The areas above $1500 \mathrm{~m}$ have more animals along with average to high yield varieties (HYV) than to the areas below of it. The economic viability of the cattle in the highland is also high because they are the major source of the economy of the populace after agriculture. In terms of to avail the fodder need, the highlands are very rich in fodder crops. In the highlands, the people hold two or more animals as an average.

The animal-household ratio in the selective villages of the region is shown in Table 3. The villages are selected on the bases of altitude, distance from the main road, and horizontal differences within the places according to the upstream and downstream basins. Distance from the road and altitude are the two main indicators of household-animal ratio, which exhibits that the highly elevated and long distanced areas of the basin are possessing high ratio in comparison to the low altitude and nearness to the road. The number of milk producing animals is relatively high in the lowland than in the highland. It is because of the feasible climatic conditions, marketing and availability of fodder. It further denotes that a village, located at the high altitude has high animal/household ratio (7), and even its goats and sheep are more in number than those of the villages at relatively low altitude. 


\section{Prospects of sustainable livestock farming}

\section{Climate and availability of fodder}

Mountain regions have the privilege of having diver's favourable geographical conditions for the sustainable development of livestock farming. But at the same time, very few mountain areas could avail this opportunity. This factor is also applied with the NEH Region of India, which obtains feasible climatic conditions and extensive grasslands, wasteland but could not get impressive position in the field of sustainable livestock farming.

Extensive Alpine grasslands are found in the entire mainland of this region, mostly in the high and medium reaches. During the summer, the cattle farmers migrate to the higher reaches along with their cattle around for four months. Contrary, they move downwards during the winter. In the low-lying areas, fodder is available as a form of crop residue, grassland, and fodder trees, which the people collect and keep it for the rainy and winter seasons. There are various sources of fodder public forest, agricultural residue, shrub land, pasture and grazing land, terrace risers and private fodder trees.

The most significant source of fodder and leaf litter (leaf litter is used as bedding material for livestock) is the public forests for the large majority of households. Degradation of forests in the mid-slopes, where concentration of population is high, has reduced the amount of fodder and leaf litter, with implications both for livestock productivity and productivity of agricultural lands.

\section{Potential areas of fodder in NEH Region}

The farmers have encouraged fodder planting on private land (agro-forestry) and more efficient collection of urine and dung for composite fertilizer. There is a theory that livestock numbers do not determine soil fertility, but rather the way in which manure is managed does. Stall-feeding, as opposed to grazing, has a greater manure retrieval rate. A large proportion of farmers have reported an increase in soil fertility on both lowland and dry upland in the roadside villages with more stall fed animals (Vaidya et al., 1995).

\section{Dairy farming}

Dairy farming is main activity and source of livelihood of livestock-dependent farming communities in the region. It involves with natural resources base-forest/rangelands, croplands, livestock breeds, feeding, health management, marketing, and consumption of the product. Smallholder dairy farming has enormous potential. It can contribute to family income, generate gainful employment especially for women, elevate living standards of the producer, fight malnutrition especially amongst children and enhances sustainable agriculture. Crop-livestock-forest integrity is a key factor to the sustainability of mountain livelihoods. Augmentation of dairy farming systems lead to the way for enhanced performance of the overall production system.

Dairy farming is an integral part of subsistence agriculture. Smallholders comprising majority of farmers are accustomed to rear some animals as an essential component of the farming system such as ploughing fields, producing manure, milk, meat, and wool. Among the various basic needs the animals fulfill, milk is the most important as far as family is concerned. Dairy animals are the best means to convert local vegetative biomass into useful products and work, and the high value biodiversity into the products of still higher value, such as dairy products fondly consumed by masses (Singh, 1995). Dairy animals therefore, occupy predominant place in the herd in NEH Region. 
Table.1 Agro-climatic zones and their crop sequences in North-Eastern Region

\begin{tabular}{|c|c|c|c|}
\hline Particulars & Climatic Zones & $\begin{array}{l}\text { Height from } \\
\text { Sea level (m) }\end{array}$ & Crop/crop sequence \\
\hline Zone-I & Alpine & More than 3500 & Pasture \\
\hline Zone-II & $\begin{array}{l}\text { Temperate and } \\
\text { sub-alpine }\end{array}$ & $1500-3500$ & $\begin{array}{l}\text { Potato-rice, rice mono cropping and } \\
\text { vegetable }\end{array}$ \\
\hline Zone-III & Sub-tropical hill & $1000-1500$ & $\begin{array}{l}\text { Rice and maize mono-cropping, maize } \\
\text { + ragi mixed, ginger and turmeric }\end{array}$ \\
\hline Zone-IV & Sub-tropical plain & $400-1000$ & $\begin{array}{l}\text { Rice and maize mono-cropping, ginger } \\
\text { and turmeric, rice-rice (irrigated } \\
\text { condition) }\end{array}$ \\
\hline Zone-V & Mild tropical hill & $200-800$ & Rice and maize mono-cropping \\
\hline Zone-VI & $\begin{array}{l}\text { Mild tropical } \\
\text { plain }\end{array}$ & $0-200$ & $\begin{array}{l}\text { Rice-rice (low land), jute / rice / sweet } \\
\text { potato mono-cropping }\end{array}$ \\
\hline
\end{tabular}

Table.2 Livestock and poultry population in North East Region (In Thousand)

\begin{tabular}{|l|c|c|c|c|c|c|c|c|c|c|}
\hline \multicolumn{1}{|c|}{ States } & Cattle & Buffaloes & Sheep & Goats & Pigs & $\begin{array}{c}\text { Horses } \\
\text { and } \\
\text { Ponies }\end{array}$ & Yaks & Mithun & $\begin{array}{c}\text { Total } \\
\text { Livestock }\end{array}$ & $\begin{array}{c}\text { Total } \\
\text { Poultry }\end{array}$ \\
\hline $\begin{array}{l}\text { Arunachal } \\
\text { Pradesh }\end{array}$ & 503 & 3 & 20 & 292 & 356 & 6 & 14 & 219 & 1413 & 1348 \\
\hline Manipur & 342 & 62 & 9 & 51 & 314 & 1 & 0 & 10 & 789 & 2403 \\
\hline Meghalaya & 887 & 23 & 21 & 365 & 524 & 2 & 0 & 0 & 1823 & 3093 \\
\hline Mizoram & 35 & 6 & 1 & 16 & 267 & 1 & 0 & 2 & 328 & 1239 \\
\hline Nagaland & 470 & 35 & 4 & 178 & 698 & 1 & 0 & 33 & 1419 & 3156 \\
\hline Sikkim & 135 & 0 & 3 & 92 & 35 & 0 & 5 & 0 & 270 & 157 \\
\hline Tripura & 954 & 14 & 4 & 633 & 264 & 0 & 0 & 0 & 1869 & 3701 \\
\hline Total & 3326 & 143 & 62 & 1627 & 2458 & 11 & 19 & 264 & 7911 & 15097 \\
\hline
\end{tabular}

Source: 18th Livestock Census, Department of Animal Husbandry, Dairying \& Fisheries, Ministry of Agriculture

Table.3 Animal/household ratio in three villages of Manipur

\begin{tabular}{|l|l|l|l|l|l|l|l|l|l|l|}
\hline $\begin{array}{l}\text { Village } \\
\text { name }\end{array}$ & $\begin{array}{c}\text { Height } \\
(\mathbf{m})\end{array}$ & Accessibility & Cows & Pigs & Buffaloes & Sheep & $\begin{array}{c}\text { Goat } \\
\text { S }\end{array}$ & Oxen & $\begin{array}{c}\text { House } \\
\text { holds }\end{array}$ & $\begin{array}{c}\text { Animal/ } \\
\text { household } \\
\text { ratio }\end{array}$ \\
\hline Litan & 1500 & $\begin{array}{l}5 \mathrm{~km} \text { from } \\
\text { main road }\end{array}$ & 62 & 106 & 35 & 56 & 79 & $\begin{array}{l}26 \\
\text { pairs }\end{array}$ & 58 & 7.7 \\
\hline Bilei & 1100 & $\begin{array}{l}\text { 6 km from } \\
\text { road }\end{array}$ & 84 & 86 & 30 & Nil & Nil & $\begin{array}{l}22 \\
\text { pairs }\end{array}$ & 89 & 2.7 \\
\hline $\begin{array}{l}\text { Purum } \\
\text { kholen }\end{array}$ & 1050 & $\begin{array}{l}\text { 10km from } \\
\text { the road }\end{array}$ & 56 & 94 & 24 & Nil & 22 & $\begin{array}{l}32 \\
\text { pairs }\end{array}$ & 75 & 3.4 \\
\hline
\end{tabular}


Table.4 Advantages of local cattle over crossbreeds or exotic cattle in NEH Region farming systems

\section{Local cattle}

1. Adapts to local feed sources and performs well on poor quality roughage and agricultural residues - more efficient at converting roughage to body weight

2. Resistant to prevailing diseases unaffected by weather extremes. Well adapted to movements in rugged terrain

3. Multipurpose - caters to diverse needs of mountain farmers- e.g., draught power, pack animal (at higher altitudes)

4. Low input at low cost

5. Reliance on externally purchased inputs and services minimal supplements, services need to be purchased

\section{Exotic breed (or crossbreed)}

1. Requires quality fodder (legumes) and concentrates for economically viable performance- uneconomical if fed on agricultural residues and roughage alone

2. Susceptible to prevailing diseases, veterinary support services mandatoryvulnerable to weather extremes. unadapted to movements in rugged terrain

3. Single purpose, e.g., milk production poor use in other diverse agricultural activities, e.g., draught power

4. High input at high cost

5. High input from outside the sy Source: Adopted from Singh (1995) and Joshi (1996).

In the NEH Region, cattle and buffaloes are the only dairying species. The use of goats and sheep as dairy animals is extremely rare. They are used for meat, wool, and transportation purposes. The species of cow and buffalo are indigenous; consequently, the milk production is low. In the valley regions, the high yield variety (HYV) jersey and Holstein cows were introduced.

Good quality fodder is prerequisite for maintenance of HYV breeds of cows and buffaloes. The main reason for poor availability of good quality fodder is very small and spatially fragmented farm size in the mainland of this region. A majority of farm households in both the hill and valley regions are marginal with land holdings below 0.5 ha, followed by small landholders with farm sizes ranging between 0.5 and 1.0 ha (Table 4).

There has been a general decline of livestock numbers in some areas, both in hill and valley where the decline per household is most prominent. Except rearing of bullocks for plowing the fields and one or two cattle for self-consuming of milk, the households do not prefer many animals. Two major factors of declining livestock populations in this region have been noticed. First is the use of chemical fertilizers in place of manure, though they are realizing the loss of soil by using chemical fertilizers and second is self-reliance of the people. Other than these factors, decrease in size of land holdings; reduced livestock feed resources, increasing population pressure and shortage of labour also deserve attention. It was noticed during field investigations that the rationale of keeping one or two number of cattle was mainly to provide milk and meat.

Livestock are traditionally significant in the state for both social and economic considerations. It is a religious practice that some household must have a cow, irrespective of its economic viability, because on many occasions, cow is worshiped. Similarly for milk, buffaloes are reared. The farming households keep a pair of or at least one 
bullock for draught purpose. However, the number and composition of animals may vary from village to village and from one household to another, according to the availability of grazing lands and the size of landholdings. The economic and religious importance of the animals in the entire region is noteworthy. The economy of the mainland of NEH Region depend mainly on agricultural practices and the animals help the farmers for plowing fields, providing manure for increasing production of crops.

During the last two decades there is a tremendous improvement in agricultural mechanization in the region has been noticed. In the mainland of NEH Region, particularly in mid-altitude, the farmers have shifted their cereal crops land into the cultivation of offseason vegetables. The return from the farmland is high in comparison to the subsistence cultivation. Large-scale emigration of farming community in the plains and the major metropolitan cities of India recede the trend of mixed-crop livestock farming. Enough remittances enhance income of farming community thus livestock population reduced.

There is a vital need to frame policies and their implementation for livestock development, considering the conservation of biodiversity both floral and faunal species. It has been observed that indigenous species of livestock are more adaptable to the fragile hill environments than the crossbreed one. Their potentials for economic enhancement of the region have yet to be utilized. A systematic study, keeping a better understanding of livestock development processes in relation to improving the livelihood of hill farmers, agroecosystem, health, and natural resources in view, is indeed inevitable. That can focus on high pressure areas of mixed crop-livestock production systems where changes are occurring in livestock composition, forage resources, natural resource management practices, livestock management technologies, the role of gender in decision-making, marketing etc.

The measures suggested for sustainable livestock farming are; (i) increase planting of fodder species (trees and grasses) on uncultivated community and private land (marginal land and terrace risers) and traditional edge of the agricultural fields. (ii) Encourage better management of common resources for fodder supply. (iii) Promote appropriate, manageable productive animals, and (iv) cattle of the region are mostly indigenous and milk production is low, while, the climate of the region is feasible for rearing improved breeds of cows and buffaloes which can be reared for increasing milk production and sustainable livelihood. Keeping terrain and availability of forage in view, promotion of dairy farming as private or public enterprises has high possibility.

\section{References}

Jhoda N.S., Shrestha S. 1990. Some Conceptual Issues of Livestock Farming in the Mountains. MFS Series No. 4. Kathmandu: ICIMOD. Pp. 56.

Land use statistics: At a glance 1996-97, Ministry of Agriculture, GOI, 2000

Mahendra Dev, S., 1994. Indicators of Agricultural Unsustainability in the Indian Himalayas: A Survey, MFS Series No. 37, ICIMOD, Kathmandu, Nepal.

National Sample Survey, 2003. Unit Level Data on Situation Assessment Survey of Farmers 18th Livestock Census, Department of Animal Husbandry, Dairying and Fisheries, Ministry of Agriculture, Government of India, New Delhi

Singh, V., 1995. Draught Animal Power in Mountain Agriculture: A study of 
Perspectives and Issues in the Central Himalayas, India. Discussion Paper. Series No. MFS 98/1. Kathmandu: ICIMOD. Pp. 74.

Vaidhya A.C., Turton K.D., Joshi J.K. 1995. 'A Systems Analysis of Soil Fertility Issues in the Hills of Nepal'. In H.
Schreier, P.B. Shah, S. Brown (Eds) Proceedings of Workshop Challenges in Mountain Resource Management in Nepal, Processes, Trends, and Dynamics in Middle Mountain Watersheds. Nepal: Lume Agricultural Centre. Pp. 123-132

\section{How to cite this article:}

Joseph Koireng, R., P.S. Rolling Anal, Kalyan Jana and Priya Devi, K.H. 2018. Prospects of Sustainable Livestock Farming in NEH Region of India. Int.J.Curr.Microbiol.App.Sci. 7(01): 1285-1292. doi: https://doi.org/10.20546/ijcmas.2018.701.157 